\title{
Voluntary Pension Saving for Old Age: Are the Objectives of Self-responsibility and Security Compatible?
}

\section{Bernard H. Casey ${ }^{a}$ and Jörg Michael Dostal ${ }^{\text {b }}$}

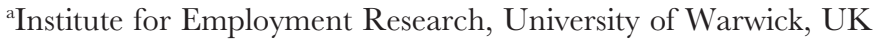 \\ ${ }^{\mathrm{b}}$ Graduate School of Public Administration, Seoul National University, \\ Republic of Korea
}

\begin{abstract}
Fiscal pressure and demographic change lead governments to seek ways of reducing state expenditure on pensions. Individuals are asked to take more responsibility, and funded, supplementary pension schemes have been established in many countries. This article looks at schemes that are voluntary the NEST or Personal Accounts scheme in Britain and the Riester Pension scheme in Germany. It examines the debate about whether it is worthwhile for some people to participate in pension schemes that are not mandatory - particularly those with low incomes and/or potentially broken careers. The small pensions they accumulate in such schemes merely offset entitlements to means-tested pension benefits, leaving them no better off in old age. Concerns about the behavioural consequences of pension means-testing are not new. Nonetheless, few policymakers have been willing to look at when and how such concerns were expressed in the context of voluntary pension savings. Equally, they have seldom been prepared to explain the costs involved in guaranteeing savings-based pensions or the implications that the lack of offering such a guarantee might have for individual behaviour. The state has sought for people to take greater 'self-responsibility' for their retirement income, but many people wish for some certainty with respect to the pensions they can expect. These goals might well be in conflict. Whether the 'state pension for the 2Ist century', as proposed by the UK government, will succeed in satisfying the objectives both of the state and of pension savers remains an open question.
\end{abstract}

\section{Keywords}

Fairness; Germany; Means-testing; Option pricing; Pension guarantees; Private pensions; $U K$

\section{Introduction}

Concern about the fiscal costs of societal ageing has resulted in initiatives to reform public pensions in Europe and across most of the industrialized and industrializing world. In a considerable number of countries, steps are being

Address for correspondence: Bernard H. Casey, Institute for Employment Research, University of Warwick, Coventry CV4 7AL,UK.Email: b.casey@warwick.ac.uk 
taken to raise the age of entitlement to a pension or to increase the number of contribution years required. In others, the level of pensions has been cut, or at least its rate of growth curtailed. However, in addition, policymakers in many countries have taken steps to encourage, or even mandate, private pension saving for old age. Private pensions are 'off the books' and so benefits paid out do not appear as part of public expenditure. Moreover, the benefits they pay out reflect, at least supposedly, the contributions made, and thus they encourage working until a higher age. They are also friendlier to mobile employees. Unlike company pensions, they are fully portable, so that job change does not lead to the employee losing rights or building up a series of small, dormant pensions with a string of employers. On top of that, of course, benefits from a private pension might compensate for reductions in, or at least curtailments in the rate of growth of, public pensions. Last, privatizing pensions is regarded as consistent with the promotion of greater 'self-responsibility' and individualization of social risk - a dominant feature of recent initiatives in the areas of employment policy, education and training policy, pension policy and health and social care policy (e.g. Delanty 2008: 686; SPG 2008; Taylor-Gooby 201 I: I48-9).

The subject of this article is the disincentives that arise for voluntary pension savings in case of the existence of a guaranteed minimum pension that is subject to a means-test. Those with low incomes during their working life might qualify for such a minimum pension, and any retirement savings they have made voluntarily will merely reduce their entitlement to the minimum pension. It is an issue that has attracted considerable attention in both Britain and Germany in recent years (e.g. Seeleib-Kaiser et al. 20II). In Britain, the government has recently proposed a 'state pension for the 2 Ist century' that is intended to remove disincentives for supplementary pension saving (DWP 20II). In Germany, too, the potential impact of means-testing on voluntary pension saving via the Riester Pension scheme has been an ongoing concern, with the suggestion that the government might establish a new 'expert commission' to evaluate the problem (Monitor 20I0). Britain and Germany are often described as having very different pensions systems - one gave rise to the characterization Beveridgian, the other to the characterization Bismarckian. However, each provides rich material for a case study of when, and under what circumstances, it is worthwhile for people to participate in supplementary pension plans and of how savers' wish for security might frustrate governments' desire to promote self-responsibility.

That disincentives to save might exist had been pointed out for the British case by Beveridge as far back as in his 1942 report on Social Insurance (Beveridge I942). It had led to his insistence that a state pension should be sufficient to ensure subsistence without the beneficiary having recourse to the indignity of application for means-tested social assistance (then called National Assistance). ${ }^{1}$ On top of this, he felt people should be free to make additional provision for themselves, and voluntary provision was certainly something he defended and advocated (see e.g. Beveridge i948). A benefit above the subsistence level was a disincentive to voluntary saving. Indeed, he saw it as 'an unnecessary interference with individual responsibilities' (Beveridge I942: para. 294). On the other hand, 'the State should make sure 
that its measures leave room and encouragement for such voluntary insurance' (Beveridge I942: para. 302). ${ }^{2}$

In West Germany, objections to high levels of pensioner poverty and dependence on means-tested benefits had been one of the factors driving the path-breaking 1957 reform that introduced a pension that linked benefits to (re-valued) past earnings - the so-called 'dynamic pension'. It was seen as a way of allowing older people to benefit from the postwar recovery and growth of the West German economy from which, until then, they had been excluded (Hockerts I980). Chancellor Adenauer declared his intention to ensure that when working people reached old age, 'they should be able to enjoy a reasonable standard of living and not have to go around like beggars' (quoted in Hockerts I980: 4I3-4). Indeed, the reform was summed up as seeking 'for once and for all time to break the traditional link between old age and poverty' (Hockerts I980: 423; Wehler 2008).

After sketching out the relevant pension schemes in the two countries in the second section of this article, the third section looks more closely at the way in which they interact with means-testing arrangements in each country. Next, the fourth section presents some of the arguments about the appropriateness of offsetting supplementary pension income against subsistence benefits that were raised in the two countries. In the case of both the UK and Germany, to allow an offset has been rejected as too costly. Thus, the penultimate section addresses in more detail the implications of guaranteeing savings-based pensions. The last section summarizes and concludes.

\section{Private Pensions in Britain and Germany}

There is a much longer history of publicly promoted private pension provision in Britain than there is in Germany. Since I988, UK employees have been able to opt out of the second, earnings-related, tier of the British state pension system (then called SERPS, now called $\mathrm{S}_{2} \mathrm{P}$ ) and have their, and their employers' contributions, diverted into a personal account that builds up a savings pot to be annuitized at retirement - a so-called Personal Pension (e.g. Pensions Commission 2004). Employees, and their employers, could make additional contributions to a Personal Pension plan, although they were not obliged to.

The initial history of Personal Pensions was not a happy one. The way in which they were 'mis-sold' to people for whom they were not suitable has been well documented. The impact of high and often opaque charges, which substantially reduced the size of the pension pot, was also the subject of criticism. It was in response to the latter that the government responded with legislation to establish Stakeholder Pensions. Charges for these were regulated and capped. Moreover, all employers with at least five employees were required to 'designate' a Stakeholder Pension and facilitate access to it for those employees who wished to join. However, employers were not required to make any contribution of their own (Pensions Commission 2004). Take-up of Stakeholder Pensions since 2000 was not large, and many of the designated schemes remained 'shells', devoid of any participants (ABI 2003). Moreover, insurance companies found the Stakeholder too constraining and not many marketed them. 
Further reform came in 2008 when, following recommendations of the Pensions (or Turner) Commission, the government introduced a quasimandatory supplementary pension scheme - then called 'Personal Accounts' - aimed at those on low to median earnings who were not members of an employer-sponsored scheme. Employees would have to opt out of membership rather than opt in. If they did opt in and paid a minimum contribution of 4 per cent of earnings, the employer would be obliged to contribute a further 3 per cent and tax relief would give the equivalent of a further I per cent. Charges were to be capped at a much lower level than applied even to Stakeholder products. The Personal Accounts scheme was scheduled to be operative from 2012 (DWP 2006). ${ }^{3}$ In 2009, it was renamed NEST (National Employment Savings Trust) and the term 'NEST accounts' is used to describe the personal accounts of those participating in it. ${ }^{4}$

Rather than being introduced in a gradual and incremental fashion as in the UK, in Germany private pensions were the product of a single reform initiative that occurred at the start of the millennium. The intention was to constrain the growth of the contribution rate to the public pension and to make necessary, downward, adjustments to benefits. To enable people to maintain income in old age, a new tier was added to the overall system - the so-called Riester Pension (Riester-Rente, named after the then German minister of labour Walter Riester). The Riester Pension constituted the first private pension system based on individual accounts to be open to German employees (Schmähl 2007). Membership was voluntary, although much of the discussion about the future development of pensions emanating from the government included the presumption that employees would have contributed to such a plan as well as to the statutory social insurance system. Employee contributions, up to a maximum of 4 per cent of salary, were offset against tax, and tax subsidies were intended to encourage particularly lower paid workers to join. The level of the subsidy depended upon income and the number of dependent children. There was no provision for an employer contribution. Approved Riester Pension savings are subject to considerable regulation, which sets out how they are managed and what the obligations of the provider are. However, this did not result in a high degree of transparency (Oehler with Kohlert 2009). Moreover, the level of charges that can be levied is not capped. ${ }^{5}$ As with respect to NEST accounts in the UK, pension savings under the Riester scheme have to be annuitized at retirement.

The number of Riester Pension policies opened rose relatively slowly. Initial hopes were for a take-up rate of between two-thirds and three-quarters of those eligible. Even by the end of 2007, five years after the scheme had been introduced, the share was little more than one third. There have been repeated calls to make the Riester Pension obligatory, from politicians, scientific advisers, employers and unions (Herden 2006; Kennedy 2007).

\section{Means-Testing and Pensions in Britain and Germany}

The value of a private pension to the individual contributing to it is illustrated in table I. Although the table describes the 'personal accounts' established 
Table I

Determinants of value of a supplementary pension

\begin{tabular}{|c|c|c|}
\hline & UK - NEST account & FRG - Riester Pension \\
\hline I. own contribution & + & + \\
\hline 2. tax relief & + & + \\
\hline 3. subsidies & N/A & + \\
\hline 4. employer contribution & + & \\
\hline 5. interest on $\mathrm{I}^{-} 4$ above & assumed + & $\begin{array}{l}\quad \text { assumed + } \\
\text { (law guarantees that own } \\
\text { contributions and subsidies } \\
\text { received returned, but only in } \\
\text { nominal terms; guaranteed } \\
\text { nominal return of } 2.25 \% \text { if in } \\
\text { form of a life assurance policy, } \\
\text { some insurers 'guarantee' more) }\end{array}$ \\
\hline 6. management charges & $\begin{array}{l}\quad- \\
\text { (structure regulated and } \\
\text { pressure to keep level low) }\end{array}$ & (structure, but not level, regulated) \\
\hline $\begin{array}{l}\text { 7. income tax/social } \\
\text { security contributions on } \\
\text { pension }\end{array}$ & - & - \\
\hline $\begin{array}{l}\text { 8. means-tested benefit } \\
\text { entitlement }\end{array}$ & - & - \\
\hline
\end{tabular}

Note: + means present and having (potentially) positive effect; - means present and having (potentially) negative effect.

under the NEST system in the UK and the Riester Pension in Germany, it is relatively generic and its principles can be applied to other schemes.

The table captures the various items that help build up the amount saved. These are items $\mathrm{I}_{-4}$. It then lists those that diminish the pot of savings or the value of the annuity paid out at retirement. Of interest here is item 8 in the table - offset against 'means-tested benefit entitlement'. Means-tested benefits can take a variety of forms and usually include, on top of direct cash assistance, benefits that cover housing costs.

\section{The interaction of pensions and benefits}

A minimum income guarantee exists in both countries. That in the UK is rather more complicated than that in Germany. Despite Beveridge's strictures, the UK Basic State Pension (BSP) has always been at a level such that those who rely solely upon it have had to claim some top-up benefit - initially to cover housing costs (Marshall i975). The guaranteed minimum income for older people (not pensioners, per se, but those over the age of 6o) was, for some time, set above the level for other groups. In I999, this provision was formally 
Figure I

How Pension Credit works

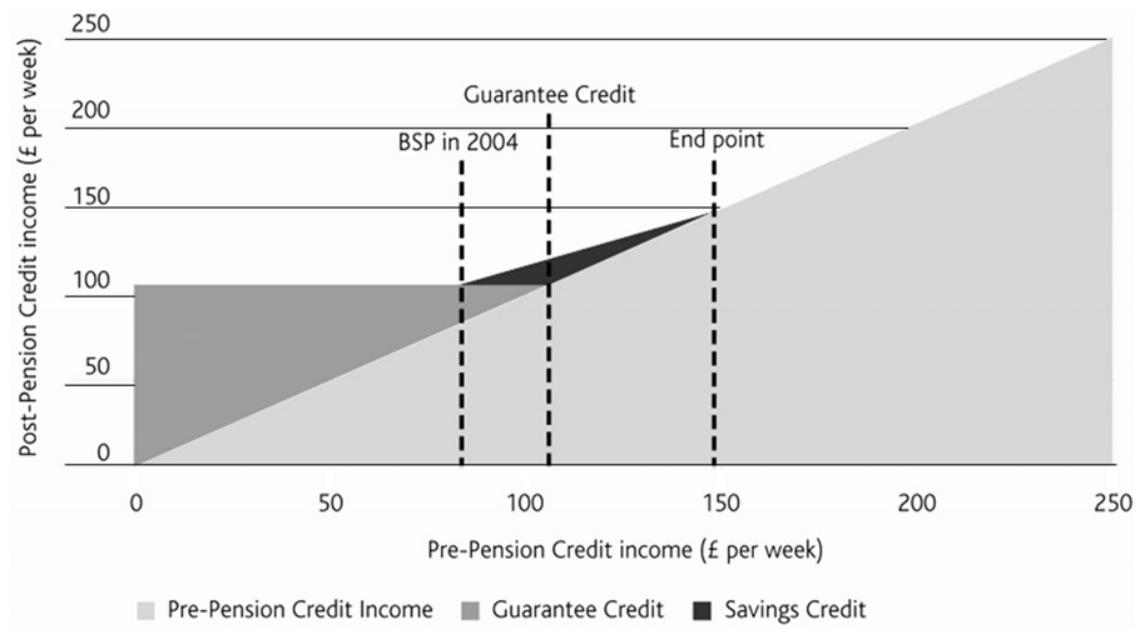

Source: Pensions Commission 2004: 227.

Note: BSP = Basic State Pension (£,77); Guarantee Credit (£, IO2); End point (£, I47). All amounts valid in 2004 .

named the Minimum Income Guarantee. Under it, as under other UK social assistance schemes, all income was offset against cash benefits, resulting in marginal tax rates of Ioo per cent. ${ }^{6}$ In 2003, the Minimum Income Guarantee scheme was changed to the Pension Credit scheme with two components - a Guarantee Credit and a Savings Credit. The intention of the latter was to provide some reward for small savers and those with small pensions. An income that is some 30 per cent higher than the BSP is guaranteed. Moreover, additional income above that can be retained until a level of total income of about Igo per cent of the BSP is reached. The marginal tax rate on income between I3o per cent and igo per cent of the BSP level is taxed at a rate of 40 per cent. Those with an income above Igo per cent of the BSP level receive no assistance. Figure I illustrates this.

However, matters are more complicated. Housing costs are taken into account when calculating minimum income. Home-owners and those paying a mortgage can enter these costs when calculating their entitlement to Pension Credit. Low-income people living in rented accommodation have to make an application for Housing Benefit and for a reduction in the tax paid to the local authority (Council Tax). Housing Benefit and Council Tax Benefit are both means-tested. When entitlement to these benefits is being assessed, income from Pension Credit is taken into account. ${ }^{7}$ The marginal tax rate applicable to Housing Benefit/Council Tax Benefit combined can be as high as 85 
per cent. Combining this 85 per cent marginal tax rate with the 40 per cent marginal tax rate for Pension Credit gives a total marginal tax rate of $9 \mathrm{I}$ per cent (Select Committee 2003). ${ }^{8}$

In Germany, older people on a low income were, until 2003, treated as all other non-workers on a low income - they could apply for means-tested social assistance (Sozialhilfe). They could also apply for means-tested benefits to cover housing costs (Wohngeld). However, the social assistance authorities are able to reclaim social assistance payments from certain family members - in this case, adult children. This discouraged many older people from making claims they were ashamed both to have to apply for help at all and to have to make calls upon their children. In order to reduce the incidence of poverty in old age and to reduce poverty that was the consequence of 'shame', in 2003 a Basic Security Income (Grundsicherung) was introduced (Steffen 2008). The new benefit, which is available to people who are over the age of 65 or are permanently disabled, is granted without a requirement for liable relatives to make any reimbursement. Moreover, instead of having to make a separate claim for assistance with housing costs, these are taken into account in assessing the benefit payable. ${ }^{9}$

In calculating the amount of assistance payable under the Basic Security Income, all sources of income are taken into account. This includes any public pension and any occupational or private pension income. Thus, the minimum income system in Germany, although it is simpler than that in the UK, involves marginal tax rates of Ioo per cent. Currently about 2.5 per cent of the population aged 65 or over are in receipt of the Basic Security Income and about two thirds of these are also in receipt of a state old-age pension or an occupational pension.

\section{Recognition of the problem}

Although the UK public pension system became not what Beveridge had wished for but rather 'a national means-tested safety net', it was generally deemed to 'have a good record' in meeting the objectives set for it (Glennester and Evans 1994: 70). Beveridge's disappointment was either forgotten or, if recalled, dismissed as unrealistic on account of the costs it implied. ${ }^{10}$ The impact of means-testing on pensions received almost no attention until it was raised in the late ig8os in a paper analyzing the 'occupational pension trap'. This suggested that as many as a half of all pensioners - many of them women on small survivors' pensions - were subject to means-testing (Walker et al. I989).

It was not until the introduction of the Savings Credit scheme in 2003 that an attempt was made to restore incentives for small savings. The Ioo per cent marginal tax rate was replaced by one of merely 40 per cent. To have made it lower, which would have meant lengthening the black area in figure I, was considered too expensive. On the other hand, it was recognized that as many as 15 per cent of all pensioners might still be facing a 9I per cent marginal tax rate (Hills 2008).

The discussion around the introduction of NEST accounts brought the subject of means-testing once again to the fore. The scheme was intended for 
Table 2

The proportion of pensioner households experiencing a positive marginal tax rate on a supplementary pension in the UK

\begin{tabular}{lrr}
\hline with a marginal tax rate of & 2005 & 2050 \\
\hline zero & $40 \%$ & $50 \%$ \\
under $20 \%$ & $10 \%$ & $10 \%$ \\
$2 \mathrm{I}-39 \%$ & $20 \%$ & $15 \%$ \\
$40-59 \%$ & $10 \%$ & $5 \%$ \\
$60-79 \%$ & $0 \%$ & $0 \%$ \\
$80 \%$ or more & $20 \%$ & $20 \%$ \\
\hline
\end{tabular}

Source: PPI 2008: chart 3 .

people on relatively low incomes and so the savings pot they would build up would be relatively small. Much emphasis was placed on keeping charges, which at the rates applying to Personal Pensions were seen as consuming over a fifth of money saved, as low as possible (Pensions Commission 2005). However, most projections of the benefits of the scheme were based on the assumption that the low-earning participants were, at least, enjoying moreor-less uninterrupted careers. The NEST accounts proposal was greeted with almost universal support, from employer organizations as well as trade unions, and from opposition parties as well as the government. It was the principal UK opposition party that raised the most concerns about whether it was 'worth saving'. This enabled it to continue to support NEST accounts in principle but to raise objections in particular (Timmins and Barker 2007).

A number of estimates, largely by policy-oriented researchers, were made of the share of people who might open a NEST account and yet find themselves losing all or part of their benefits. One study assumes that by 2050, when the new scheme would be fully mature, 50 per cent of pensioners might still be subject to means-testing - only ten percentage points fewer than the number today. The same study (see table 2) suggests that the number facing marginal tax rates of at least 80 per cent was likely to be unchanged by that date (PPI 2008). ${ }^{11}$

In Germany, the 200 pension reform attracted considerable attention. It was characterized as involving paradigmatic change. One element of this change - the introduction of a new, funded tier - has already been described. The second and equally important element was the switching of the public pension scheme from what was in many ways a defined benefit system to a defined contribution system. Henceforth, rather than contribution rates being driven by benefit levels and the size of the pensioner population, benefit levels would be driven by contribution rates and these would not be allowed to rise beyond a given level (Schmähl 2007).

It was quickly recognized that the new benefit calculation formula reduced the level of the pension that people were likely to collect. It was also recognized that, all things being equal, more years of contribution would be needed 
Table 3

Years of contributions needed to avoid means-testing in Germany

\begin{tabular}{lcc}
\hline people earning & 2008 & 2030 \\
\hline $50 \%$ of average wage & 56 & 68 \\
$70 \%$ of average wage & 37 & 45 \\
average wage & 28 & 34 \\
\hline
\end{tabular}

Source: Steffen 2008: chart 2.

to ensure that the accrued pension was above the social assistance level. Examples of such calculations are given in table $3 \cdot{ }^{12}$

One of the reasons for promoting supplementary pensions was that they would enable employees to repair the reduction in benefits available from the public pension system. On the other hand, although the legislation that introduced the Riester Pension was the same legislation that introduced the Basic Security Income, there was no acknowledgment of the possible conflict between the two measures in any of the contemporary debates - either in parliament or amongst the scientific community (see Deutscher Bundestag 200I). ${ }^{13}$ The first time the contradiction between the two measures was aired widely was when the 'scandal' of the offset was analyzed in a radio programme in late 2007 (Sozialverband 2007). The issue was picked up by a number of opposition politicians and resulted in a series of parliamentary questions (Rohde and Fraktion der FDP 2007; and, subsequently, Ernst and Fraktion DIE LINKE 2008).

Wider public interest was first awakened by a television programme at the start of 2008 (WDR 2008). This reported that people on an average income but with fewer than 32 years of contributions to the public pension scheme would be eligible for the Basic Security Income. Any Riester Pension income they might receive would simply reduce their entitlement to benefit. How many were likely to be in that situation was rather unclear. 'Experts' were, however, quoted as talking of 'millions', whilst a former Christian Democrat labour and social affairs minister entered the debate with the claim that by the time recent reforms to the public pension system had taken effect, as many as 20 per cent of over-65 year olds would be on means-tested benefits (Blüm 2008).

\section{The Debate in Britain and Germany}

In both the UK and Germany, the realization that there might be no advantage in participating in supplementary pensions that the respective governments were promoting produced a fierce, if somewhat brief, debate. This debate focused on two main issues - namely whether means-testing was fair, and whether the difficulty of determining who might be affected by 
means-testing might further discourage pension saving. These two questions, which often overlapped each other, are examined in turn below. However, the way in which the governments responded to them was ultimately determined by their views about the cost implications of removing the offset. A discussion of the nature of these is reserved for the following section.

\section{The unfairness of means-testing}

The fact that pension income offsets entitlement to means-tested benefits has led some to suggest that governments had a hidden agenda in promoting supplementary savings plans. As the ig89 UK study put it, "that element of the pension that serves to offset the entitlement to [benefit] shares many of the characteristics of a direct tax' (Walker et al. I989). A similar argument was made in Germany, again by an academic, although not in a scientific publication, who suggested that those who contributed to a Riester Pension were behaving 'nobly', thereby ensuring that they did not become a burden to 'society' and the 'taxpayer' (Miegel, quoted in Plusminus 2008).

Others saw it not as the employee who was relieving the social assistance budget but rather the employer. This argument had some relevance in the UK because, once the employee had decided not to opt out of the NEST accounts scheme, the employer would be obliged to make a contribution into the pension plan that had been chosen. Echoing the arguments from Germany about 'nobility of behaviour' on the part of the employee, one consulting actuary described the NEST accounts scheme as 'well-meaning' but suggested that employers be permitted to point out to their employees that they might lose out on means-tested benefits if they had pension savings. Moreover, because employers were also required to contribute, the scheme was 'tantamount to imposing a new tax on employers to subsidize the cost of means-tested benefits' (Branford 2008).

On the other hand, there were those who argued that it was legitimate for the state to claw income back because it, initially, had subsidized the pension savings. Thus, in the UK, the 40 per cent marginal tax rate has been argued as not posing a major disincentive to save because the amount withdrawn is 'offset by ... the combination of the 3 per cent employer contribution and the tax relief [granted]' (Turner 2008). In addition, in so far as the contributions they made reduced their disposable income, the amount of tax credits that low-paid employees could claim to top up their current income was increased. There were, indeed, further subsidies for those who were living in rented accommodation and, thus, were eligible for Housing Benefit. For such people, contributing to a pension would reduce their disposable income and increase, by 50 per cent of this amount, the amount of tax credit or Housing Benefit that they would receive (Hills 2008).

In Germany, it was the subsidies made by the state for contributors on low incomes and with several children that were referred to. For some, the size of the subsidy dwarfed the employee's own contribution to the Riester Pension - in extreme cases, it could amount to go per cent of the total that flowed into the savings account (Deutsche Bundesbank 2002). In other words, in so far as it was the state that was paying for the pension that took the person over the 
Basic Security Income, it was legitimate for the state to take this income into account when assessing whether somebody was in need of social assistance (Riester 2008).

Another response to critics of the means-test was that, if Riester Pensions were to be disregarded, a floodgate would be opened. Other sources of income, too, would have to be disregarded, and this would make a mockery of the Basic Security Income scheme or, indeed, the whole social assistance system. Employing a reductio ad absurdum approach, it was suggested that not only would private pension savings have to be ignored, so too would income from the public pension system (Riester 2008).

\section{The uncertainties of means-testing}

All projections about the future are based upon assumptions. These assumptions can vary, but one thing they reflect is uncertainty. Individuals who have to decide whether or not to contribute to a supplementary pension scheme face this uncertainty. They are also confronted by the complexity of a number of benefit systems interacting with one another in manners that are not transparent. This has been recognized by some of the advocates of reform. Even the UK Pensions Commission saw a problem here, although it did not pursue it (Pensions Commission 2005). Evidence from ad hoc consumer surveys underlines the extent to which consumers might find themselves confronted with potentially insurmountable problems. Thus, a recent survey found that about a third of working adults would be put off from saving for a private pension because of the impact of means-testing, and amongst people in the I6-29 age band the share was as high as 40 per cent (Scottish Widows 2008).

A study undertaken by the UK Department for Work and Pensions (DWP), using 'extensive analytical modelling' and the construction of hypothetical examples, came to the conclusion that 'there is no readily identifiable group in the working-age population whose members would not, on average, gain back more than they put in to a pension' (DWP 2009: 2-3). However, the DWP emphasized that it did not take account of how savers might behave. Rather, the study was intended to reassure those who had to market pensions that they had few grounds to fear subsequent accusations of mis-selling (interview with DWP on in February 2009).

Surveys on what individuals in Germany felt about means-testing do not appear to be available. Nonetheless, a poll dating from the spring of 2008, and after the television programme that had first exposed a potential 'Riester scandal', showed how a large majority of the population feared that poverty in old age was a growing problem (N24-EMNID 2008). Commentators in Germany have made it clear that there are certain people who should not open a Riester Pension. The frequently advanced example is the person on a low wage and aged in his or her 50 Os (Brandstetter 2008; Abendblatt 2008; SWR 2008). It was much the same people who were identified as potential (not actual) losers in the analytic study undertaken by the UK DWP (DWP 2009). However, simply because a younger person is on a low wage at present is not considered a reason not to participate. To refuse to do so is said to 
display undue pessimism - that one's career will not progress. One commentator in the UK argued that advising people not to subscribe to a NEST account because a series of bad luck in personal as much as work life might result in them falling into the Ioo per cent marginal tax rate trap, was like arguing that people should regret having taken out home insurance because their home had not been burgled (Turner 2008).

If liability to a Ioo per cent marginal tax rate cannot be presumed for categories of people, and it is only by close examination of a person's circumstances that it is possible to tell whether participation is worthwhile, it could be argued that potential subscribers need thorough advice. The validity of this argument is recognized. Some, for example the UK Consumers Association, feel that the generic advice available to all potential subscribers is adequate (Which? 2007). Others believe it is not. However, were thorough advice to be given, the costs of provision would be high. This would defeat the purpose of the NEST accounts scheme, which was to deliver a plan where savings would not be eaten away by selling and management charges (Hills 2008). At this point in time, and indeed for longer, the UK government subscribed to this view.

\section{The Implications of Guaranteeing Savings-Based Pensions}

One of the justifications for moving pension provision from one based upon pay-as-you-go (PAYGO) principles to one based on funding has been that a far higher return is thereby achievable. Some have even argued that a switch to funding could generate higher returns for lower contributions (Feldstein I997). ${ }^{14}$ They point to how, over the longer term, the notional rate of return of a PAYGO system depends on a combination of labour force and productivity growth and that, whilst productivity might continue to grow, the labour forces of many industrialized countries are projected to stabilize or even decline. They also show how, at least over extended periods, the value of equity markets has grown substantially. If this is the case, it might seem surprising that governments refuse to guarantee that a funded pension scheme will return even a minimal level of benefits or, where means-tested minimum income schemes operate, that participation in a voluntary supplementary pension system will be worthwhile.

\section{The cost of insuring pension guarantees}

Most exercises intending to show the value of defined contribution supplementary pension plans are conducted using the assumption that the amount contributed will earn a specific rate of return and will earn it consistently for as many years as contributions are made. Sellers of private pension plans produce projections on this basis as part of their marketing activities. So, too, does the European Commission when it is projecting the contribution made by defined contribution pension schemes to total replacement rates for employees in relevant EU member states, and so, too, do the governments of the UK and Germany when they are carrying out similar exercises (ISG 2009; DWP 2006; BMAS 2008). ${ }^{15}$ The UK government also used this approach 
when searching for groups that might lose out by contributing to NEST accounts (DWP 2009).

Of course, equity markets do not deliver a steady rate of return year in year out. They are volatile, and the probability of falling below any target return in any one year is quite high. However, advocates of defined contribution plans rely on the contention that, for a given level of volatility, the probability of failing to reach any target rate of return declines with time. ${ }^{16}$ The UK Pensions Commission felt justified in proposing that employees be encouraged to participate in funded plans to supplement their retirement incomes. It pointed to the low probabilities of equity markets failing to achieve long-term returns when investments were made for long periods as they would be when it was a pension that was being built up (Pensions Commission 2005: ch. 5). On the other hand, if the probability of failing to meet a target is low, the question of why the UK government will not guarantee any target for NEST accounts and, equally, of why the German government will not make more than the most minimal guarantee with respect to a Riester Pension, or why any other government is equally cautious with respect to similar products, needs to be faced. ${ }^{17}$

The answer lies in the fact that for people contributing to a pension, what matters is not merely the probability of their investments failing to achieve the target rate of return but the size of the failure if it occurs. There will be an average shortfall, but some shortfalls will be bigger and some smaller - in other words, shortfalls will have their own volatility. Unlike the volatility of the rate of return, which declines with time, this volatility increases with time. Losses (and gains, but it is losses that count for the purpose of guarantees) are compounded, because shortfalls affect the total accrued so far and not merely the amount contributed in any one year. ${ }^{18}$

To provide a guarantee is to provide insurance against such a shortfall. To buy insurance that an investment will indeed have a certain value at some point in the future is referred to as buying a 'put option'. ${ }^{19}$ The cost of such an option, and so the cost of the insurance policy, rises the greater the distance into the future covered by the insurance contract. ${ }^{20}$ Figure 2 provides a stylized illustration of this, whereby the policy ensures that at least the 'risk free' rate of return - the return available from investing in indexed government bonds - is achieved. ${ }^{21}$

The cost of insuring against an unlikely but potentially catastrophic outcome constitutes the principal reason why governments, despite suggesting that saving is worthwhile and pointing to the low probability of a shortfall, are not prepared to provide a guarantee for the supplementary pension plans they promote. ${ }^{22}$ Although contributors rather than the government might be asked to pay the insurance premium, they are unlikely to be willing to do so. From their perspective, it would seem as if they were contributing extra but not building up a bigger pension pot by doing so. The addition to the pension contributions would appear as money lost, even if, to refer to an argument made earlier, it might be no more lost than are house insurance premia paid on a house that never burns down.

Insurance costs would be lower than those described so far if the purchaser of the policy were prepared to forego the upside risk - returns in excess of the 
Figure 2

Probability of shortfall and cost of insurance

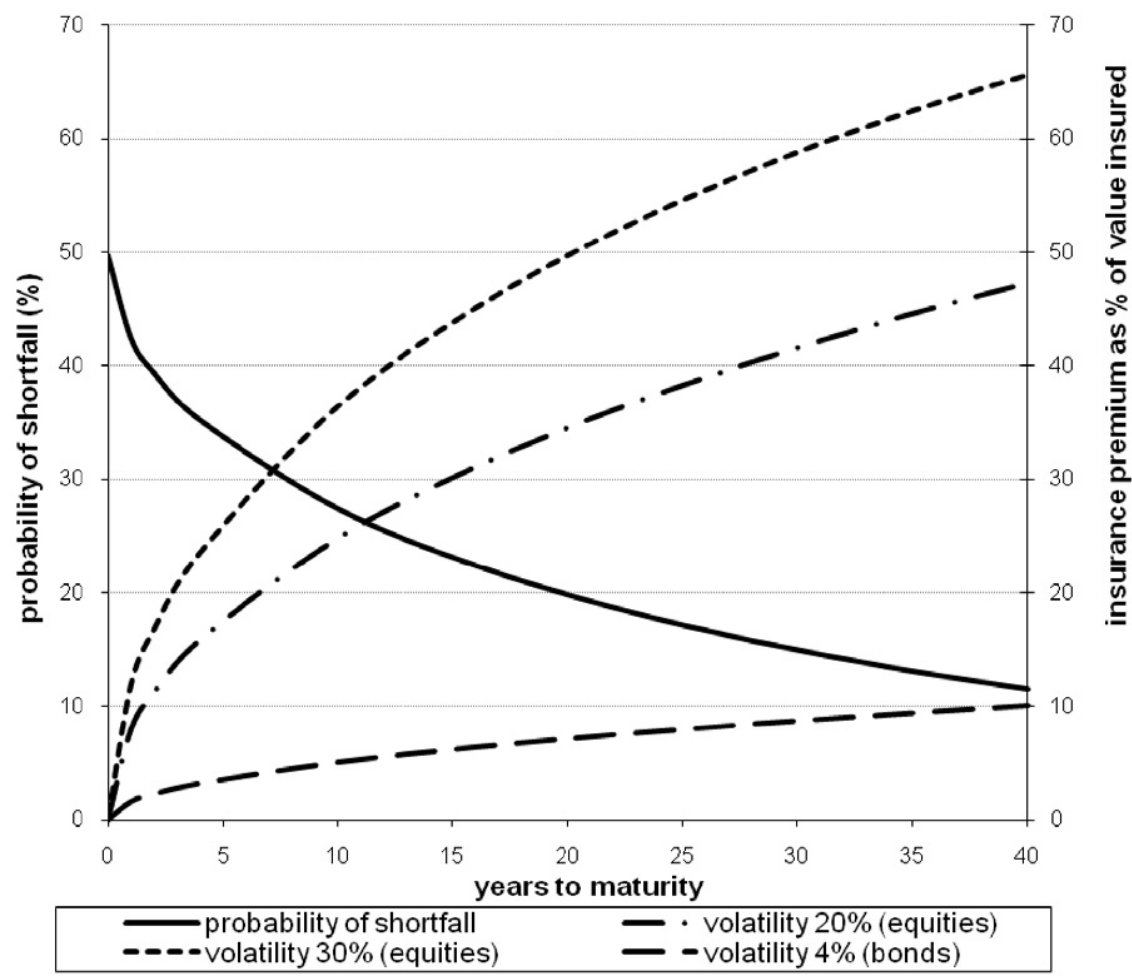

Note: The probability of a shortfall is the probability that returns will be less than 5.5 per cent per year and where the one-year volatility is 20 per cent. The 5.5 per cent is the median real rate of return on UK equities used in the UK Pension Commission illustrations. The 20 per cent volatility approximates the standard deviation of rates of return calculable for both UK and US equities over the long term. The 4 per cent volatility approximates the volatility of rates of return on investment grade bonds. The 30 per cent volatility is included for illustrative purposes.

target rate - and did not merely wish to buy protection against the downside risk. The insurer would reap the benefit every time the investment exceeded the guaranteed value. On the other hand, from the contributor's point of view, such a pension becomes less attractive. At the extreme, when upside risk is completely surrendered, the contributor would have been assured to receive neither more nor less than the risk-free rate of return. A product offering this could have been chosen at the start, and if it had been chosen, there would have been no need for insurance. ${ }^{23}$

If supplementary plans such as NEST accounts and the Riester Pension cannot be guaranteed a given level of return, neither can they be guaranteed 
to bring savers' incomes above a minimum level. Moreover, in so far as governments guarantee any return at all, by doing so they might encourage morally hazardous behaviour. Ex post, there might be few occasions when contributors would have failed to achieve the sort of modest returns that, for example, the UK and German governments assume. Nonetheless, knowing they were protected by a guarantee might lead people to choose more risky investment strategies. They would be 'less responsible' when it is precisely 'self-responsibility' that is being sought. Governments, thus, tend to limit their activities to enhancing financial literacy, indicating the implications of different investment strategies, making sure that the relevant products are available for savers and/or ensuring that the products being marketed meet relevant standards. They might go so far as to establish default savings plans and products, including those that shift savers into less volatile products as they come closer to retirement. ${ }^{24}$

\section{The Gitizen's Pension Alternative}

The means-testing problem is avoided only if a mandatory pension already places people on an income that is above subsistence. However, in the UK, providing such a pension was rejected as too expensive at an early stage.

Proposals for some kind of 'demogrant' - a non-contributory or taxfinanced pension - have been made many times in the postwar years, both in the UK and in Germany. The UK government reappraised a Citizens Pension at the same time as it was concretizing its proposals for the NEST accounts scheme, but turned it down on cost grounds (DWP 2006). In Germany, calls for the introduction of a Volksrente or Grundrente were made with renewed vigour when it was realized that income from a Riester Pension could be offset against entitlement to Basic Security Income. Some proposed a reform to the public pension system to ensure that all who had worked at least 35 years would receive a pension above the social assistance minimum (Braun 2008). In effect, this would have restored a benefit (the so-called Rente nach Mindesteinkommen) that had existed West Germany until it was abolished in the I989 pension reform. Those who thought their proposals through were aware that these involved substantial cost (Geißler, quoted in Lau 2008). ${ }^{25}$

The problem of poverty in old age was the principal theme of the 'pension dialogue' that the German labour and social affairs minister convened in autumn 20II. There, employers, trade unions and interested nongovernmental organizations discussed the projected decline in future pension levels and, in particular, its impact on people who had had low earnings for much of their working lives. The minister proposed a new Top-Up Pension (Zuschussrente) that would be higher than the Basic Security Income. To qualify, people would have to show they had contributed to the public pension system for a very long time -45 years of which no more than io could be made up by credits for periods spent on childcare, etc. (Schwenn 2012). In addition, they would have to show that they had contributed to a supplementary pension, such as an occupational or Riester pension, for at least 35 years. For those who did the latter, the minister argued: 'Riester savings would always pay off' (MDR 20II). ${ }^{26}$ 
In the UK, criticism of the NEST system remained persistent. Moreover, the onset of the 2008 economic crisis led some to repeat calls for a delay in its roll-out, as well as for the exemption of very small firms and of employees who had not completed at least three months employment. With the exception of the last of these demands, the by then new government made no concessions (DWP 20I0). On the other hand, it did prove more receptive to the argument that, 'Unless it tackles the means-testing trap, the government faces a major mis-selling scandal' (Tomlinson 20II), and to the associated call for a thorough-going reform of the state pension that would provide a benefit that made saving worthwhile. Hints were being dropped in late 2010 that this was being contemplated (BBC 20IO) and, by spring 20II, the various ministers were endorsing such a proposal. A consultation document laid out the broad framework that was being considered and this contained repeated reference to the need to remove the 'complexities' and 'anomalies' of current arrangements (DWP 20II).

That a 'state pension for the 2Ist century' would, if it were to be high enough, entail costs, was recognized. The new pension would integrate the current BSP and $\mathrm{S}_{2} \mathrm{P}$ benefits into one single, flat-rate benefit. Those who would have received a pension via the two schemes above that level would be losers under the new system, whilst those who would have received less would be gainers. To finance the reform, additional resources would be generated by the abolition of the rebates on national insurance contributions granted to those who were members of an occupational defined benefit pension plan. Both the members of such schemes - who tend to be better paid employees and their employers would have to bear this cost. ${ }^{27}$

Were it to be introduced, such a pension would reduce the risk faced by low earners, but it would not remove it entirely. Those who had substantially incomplete careers might not be entitled to the full pension. Equally, those who were claiming further assistance such as support for housing costs, might still find themselves subject to the means-tests applied by these schemes (see e.g. NAPF 2005).

\section{Conclusions}

Demographic ageing has led governments across the world to reduce the generosity of public pension provision. In the case of the UK and Germany, the consequence has been an element of convergence between pension regimes that were, initially, rather different. In the UK, under the welfare state that was established after the Second World War, the public pension was a flat-rate benefit. For a limited period, an earnings-related component was added, but this proved too expensive and the supplement as currently constructed will be for many no more that a further flat-rate benefit. In West Germany, under the social market economy that was being built up in the I950s, the public pension became proportional, albeit subject to floors protecting low earners and ceilings penalizing high earners. However, the 200 I reform substantially changed this. Although the proportionality principle was maintained in the accrual formula, it became clear that a minimum pension would be the best that many would achieve. Moreover, many would receive 
a pension that required them to make a call upon a means-tested benefit. The extent of convergence was reinforced by the way in which governments in both countries gave an increasing role to individual savings plans to produce an adequate level of retirement income.

Means-testing lies uneasily together with the promotion of selfresponsibility and saving. Such incompatibility might be unproblematic when only a small proportion of the pensioner population is potentially affected by means-testing. Means-testing was, however, never a marginal phenomenon in the UK. Nor, according to most projections, will it remain one in Germany. Moreover, there is evidence that people are aware of the trap into which they might fall. Their fears might be exaggerated.

Subject to reasonable investment performance and an acceptable work history, most employees might be able to increase their living standards in old age by participating in a supplementary pension savings plan. Nonetheless, some might not and, if failures occur, contributors will be left with much lower pensions than they were led to expect. Governments, although they promote savings-based supplementary pension plans, are aware that, for some savers, on some occasions, some plans will fail to deliver. They are not prepared to guarantee against failure to deliver because to do so would contradict their intention of taking pension obligations 'off the books' and would discourage 'self-responsibility'. Even proposals to ensure that pension savings do not reduce entitlement to means-tested benefit will be resisted for precisely these reasons. For a long time, the UK government denied that means-testing threatened the viability of its proposal to introduce a supplementary, savingsbased pension. Finally, it was obliged to concede that the latter would only be a success if there were a complementary reform that improved the value of the public pension.

Last, it is worth noting that the groups targeted by the NEST scheme or the Riester Pension scheme tend not to be highly financially literate. They tend to be risk averse and favour security in old age. ${ }^{28}$ They have observed volatile stock markets. ${ }^{29}$ They have experienced the growing incidence of employment interruptions and non-standard working that bring with them volatile earnings. Schemes such as NEST and the Riester Pension might add to income in old age, but the refusal of governments to offer any guarantee that it will - and thus to guarantee that small savings are worthwhile - does not add to a sense of security. This is something that the UK government appears to have learnt. It is something that the German government may still have to learn.

\section{Acknowledgements}

Much of Bernard Casey's work on this article was financed under the $\mathrm{FP}_{7}$ programme of the European Commission via the project GUSTO (governance, uncertainty, sustainability - tensions and opportunities).

\section{Notes}

I. For Beveridge (I942) this was one of the 'fundamental principles' of social insurance. See, for example, para. 294: '[A] permanent Scale of benefit below subsis- 
tence, assuming supplementation on a means test as a normal feature, cannot be defended'. Paragraph 307 states: 'Adequacy of Benefit: the fourth fundamental principle is adequacy of benefit in amount and in time. The flat rate of benefit proposed is intended in itself to be sufficient without further resources to provide the minimum income needed for subsistence in all normal cases'.

2. Beveridge was not the first to make this argument. As far back as the I8gos, and following the introduction of a pension in Germany, trade unions in the UK had been demanding similar action at home. However, they had insisted the pension be universal - any element of means-testing both had connotations of the Poor Law and would have questioned the small retirement savings schemes they already operated (Blackburn 2002: 47-9).

3. Employers also had the option to place employees into an existing occupational pension scheme as long as this offered at least equivalent benefits to those foreseen in the relevant legislation.

4. The actual implementation date for NEST has been subject to repeated alteration. It was to be phased in, so that first larger employers and then successively smaller employers were involved. Moreover, the employer contribution, itself, was to rise in stages. This second element of the implementation has been unchanged, but whilst large employers will have to be compliant by 2012, implementation by small employers (those with fewer than 50 employees) has been further postponed - from 2014 to, at earliest, 2015. The intention was to relieve small firms and help them cope with the 'current crisis'.

5. At the same time as the Riester Pension was introduced the government also legislated for a 'salary sacrifice' scheme - the so-called Eichel Pension that took its name from the then finance minister. This enabled tax free contributions to be made into occupational pension schemes, if these existed. The Eichel Pension is more favourable to higher earners, especially those without dependents.

6. The marginal tax rate is the tax paid on one extra unit of income received. Here a 'marginal tax rate of $\mathrm{I}$ oo per cent' means that any extra $f \mathrm{I}$ of income is taken away completely.

7. One further complication that is not discussed in this article is that of 'asset tests'. The various minimum income and assistance provisions described so far are payable only to those with assets below a certain level. That level differs for different benefits. See, for example, Spicker 201 I.

8. There is yet another group that also faces a Ioo per cent marginal tax rate people who have not made a sufficient number of contributions to earn a full BSP. The Guarantee Credit assumes that a person has a full pension. If the BSP is below this level, any additional income, including any occupational or private pension income, is counted towards making up the difference and so is taxed at Ioo per cent. This marginal tax rate has tended to have its greatest impact upon women. As of 20I0, the number of contributing years to the BSP has been cut from 39 for women and 44 for men to 30 for all people.

9. In fact, an income test does remain. If liable relatives have an income in excess of

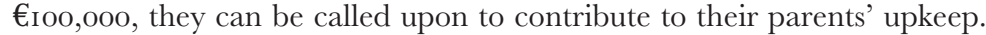

Io. Beveridge's disappointment, expressed in a speech to the House of Lords in I953, is referred to in Marshall 1975: 90.

II. As before, the assumption was that those affected would mainly be women, who tend both to be lower-paid and to experience more interrupted careers.

I2. In most cases, the discussion about the level of the public pension relative to the level of income guaranteed via means-tested benefits is conducted with reference to a single person. However, entitlement to means-tested benefits is assessed on the basis of household income. It might be assumed that, in many pensioner 
households, there are two pensions and, in such cases, income would increase. But so, too, would the minimum income required. There is no suggestion in the German debate that concentration on a single person's pension when making illustrative calculations distorts the extent to which more and more pensioners (and so pensioner households) will find themselves liable to means-testing.

I3. A perusal of German social policy periodicals - Sozialer Fortschritt, Zeitschrift für Sozialreform, Soziale Sicherheit - revealed no references to possible conflicts of policy being made in the years $2000-07$.

I4. This argument has been subject to substantial criticism. Examples include Orzag and Stiglitz 2001; Barr 2002; Barr and Diamond 2006.

I5. The UK government and the Turner Commission, which influenced its thinking, presumed a 4 per cent rate of return and then deducted charges of 0.5 per cent so giving a net return of 3.5 per cent. The European Commission calculations are based upon a 2.5 per cent net return.

I6. This assumes that, in the same way that investing in many different assets or classes of asset rather than in only one diversifies risk, so too does holding any one asset class over many time periods. If annual investment returns are independent of each other, the formula for calculating the volatility of the return includes the number of years for which returns are observed in its denominator. In other words, the more returns that are observed, the narrower is the range within which a given share of them fall. This result draws from a component of basic statistical theory whereby the standard error of a sample (s.e.) $=\sigma / \mathrm{vn}$. Sigma $(\sigma)$ is the population standard deviation, here the measure of 'volatility', and vn is the square root of the number of observations, here years for which information is available. A volatility of around 20 per cent has often been calculated for the equity markets of many countries of the Organisation for Economic Co-operation and Development when long-run annual returns are analyzed.

I7. Over and above the uncertainty of how much might be in members' accounts when they come to retire is the uncertainty of what level of pension that amount will purchase when it is annuitized. This depends upon unknowns such as future longevity as well as the yield on (government) bonds. Increases in longevity and falls in benchmark interest rates both depress the value of the annuity achievable for any size of pension pot.

I8. In this case it is not the volatility of annual returns that is considered but the volatility of total returns. The relevant formula for this is an increasing function of the (square root of the) number of years observed.

I9. Farmers producing commodities, the price of which is highly volatile, also purchase put options - insurance that they can sell the commodity at a particular price. If that price is exceeded, they have paid insurance but not benefited in the period in question. If the market price is below the insured price, the insurance has been worthwhile in the period in question.

20. The formula for calculating the price of insurance derives from Black-Scholes option pricing theory (Black and Scholes I973). What is to be noted is that, in the relevant formulas, both volatility and (the square root of) time enter in the numerator. Thus, the cost of the insurance premium is an increasing function of both variables. A rule of thumb that allows an approximation of the insurance premium $(\mathrm{P})$ as a proportion of the initial stock price $(\mathrm{S})$ is $\mathrm{P} / \mathrm{S} \approx 0.4 \sigma \mathrm{vn}$ (Bodie and Merton 2000). This makes clear how both volatility and time are important. A good, albeit relatively technical exposition of the cost of insuring returns in the equity markets, which also applies it to guaranteeing pension schemes, is to be found in Bodie i995. For a recent exercise, although based upon a somewhat different approach, see Munnell et al. 2009. 
2I. The risk free rate is less easy to determine empirically than it is conceptually. However, long-term (25 year), indexed government bonds - which might be considered to provide a match for people saving in pension plans - were yielding an average of 1.74 per cent per years in real terms over the years 2000-06 - i.e. before the onset of the 'credit crisis'. This is considerably less than the real rate of growth of the economy - approximately 2.7 per cent per annum.

22. For example, the UK government stated 'NEST accounts will build funds on a defined contribution basis. As with all defined contribution products, the value of the individual's fund can fluctuate over time due to changing investment performance. For example, the value of stocks and shares can decrease as well as increase. ... There is no absolute guarantee that the value of the fund would be more than the value of the contributions invested, and that there would be investment growth. The value of these investments therefore cannot be underwritten by government' (DWP 2009: para. I.75).

23. Examples illustrating this can be found in Munnell et al. 2009.

24. This is frequently referred to as 'life-styling' and switches investments from volatile equities to less volatile, interest bearing bonds as the saver gets older. Such an approach has been proposed for the default option under the UK NEST accounts scheme.

25. Such a reform would not, in fact, help those with the highest risk of poverty in old age. It has been calculated that two-thirds of female contributors would not be helped by such a reform (Bogedan and Rasner 2008).

26. The statement of the minister might be misleading on two counts. First, the total worth of the Basic Security Income might be more than the $€_{374}$ of the benefit itself. This is because the recipients of Basic Security Income are also able to claim assistance for rent and heating and are covered by the health and social care insurance systems. Recipients of the €850 Top-Up Pension would not be entitled to these passported additional benefits. Second, the Top-Up Pension might still be means-tested at the level of the household. However, details of means-testing rules have not yet been confirmed (personal communication, German Ministry of Labour and Social Affairs, ig March 2012).

27. Although it was not directly 'part of the package', the government had also expressed its intention to accelerate the pace at which the pension age was to be increased. For women, it will be brought to 65 by 2018 and for both men and women it will rise to 66 in 2020.

28. Studies showing risk aversion being negatively related to wealth are plentiful. Those showing risk aversion relative to income are much less common. For a review of the relevant literature, see Meyer and Meyer 2006. For a study of attitudes to risk amongst potential NEST savers in the UK, see Thomas et al. 2009.

29. It is worth noting that the NEST Corporation, which runs NEST, has issued investment guidelines for its default fund that ensure that, for the first few years, members' contributions are invested in fixed income and other safe assets. This is to ensure that members will not see dramatic drops in their income that might discourage them from continued participation. Such investments will apply even for young people, whom even advocates of lifestyle investing would normally advocate can afford to invest in equities because they can afford to 'be in for the long run' (see NEST 2011).

\section{References}

Abendblatt (2008), Dritte 'Säule' fürs Alter Riester-Rente: 'Für die meisten lohnt sie sich', Hamburger Abendblatt, I2 January. 
Association of British Insurers (ABI) (2003), Stakeholder pensions - time for change, London: ABI, http://www.abi.org.uk (accessed 20 October 2009).

Barr, N. A. (2002), Reforming pensions: myths, truths, and policy choices, International Social Security Review, 55, 2: 3-36.

Barr, N. and Diamond, P. (2006), The economics of pensions, Oxford Review of Economic Policy, 22, I: I5-39.

BBC (20I0), Vince Cable vows 'decent' state pension for all, 25 October, http://www.bbc.co.uk/news/uk-politics-II6r8org (accessed 20 April 20I2).

Beveridge, W. H. (1942), Social Insurance and Allied Services: A Report by Sir William Beveridge, Cmd. 6404, London: His Majesty's Stationery Office.

Beveridge, W. H. (I948), Voluntary Action: A Report on Methods of Social Advance, London: Macmillan.

Black, F. and Scholes, M. (I973), The pricing of options and corporate liabilities, Fournal of Political Economy, 81, 3: 637-54.

Blackburn, R. (2002), Banking on Death or Investing in Life: The History and Future of Pensions, London: Verso.

Blüm, N. (2008), Blüm antwortet Riester, 20 May, http://www.nachdenkseiten.de/ ?p $=3232$ (accessed 20 October 2009).

Bodie, Z. (I995), On the risk of stocks in the long run, Financial Analysts Fournal, May-June, I8-22.

Bodie, Z. and Merton, R. (200o), Finance, New York, NY and London: Prentice Hall.

Bogedan, C. and Rasner, A. (2008), Arbeitsmarkt x Rentenreformen = Altersarmut? WSI Mitteilungen, 3: I33-8.

Brandstetter, B. (2008), Altersvorsorgedebatte: Riester-Rente rechnet sich doch, Die Welt, i January.

Branford, J. (2008), Pension opt-out 'inducements' to be outlawed, Investment and Pensions Europe, 24 June.

Braun, S. (2008), Jürgen Rüttgers und die Rente: 'Die CDU stellt sich dem Problem der Altersarmut', Süddeutsche Zeitung, 5 May.

Bundesministerium für Arbeit und Soziales (BMAS) (2008), Alterssicherungsbericht 2008, Ergänzender Bericht der Bundesregierung zum Rentenversicherungsbericht 2008 gemäß § I54 Abs. 2 SGB VI, Berlin: BMAS.

Delanty, G. (2008), Fear of others: social exclusion and the European crisis of solidarity, Social Policy \& Administration, 42, 6: 676-9o.

Department for Work and Pensions (DWP) (2006), Personal accounts: a new way to save, London: DWP.

Department for Work and Pensions (DWP) (2009), Saving for retirement: implications of pensions reforms on financial incentives to save for retirement, Research Report no. 558, London: DWP.

Department for Work and Pensions (DWP) (2010), Making automatic enrolment work. A review for the DWP, London: DWP.

Department for Work and Pensions (DWP) (20II), A state pension for the 2Ist century, London: DWP.

Deutscher Bundestag (200I), Plenarprotokoll I4/I47, Stenographischer Bericht, I47. Sitzung, Berlin, 26 January.

Deutsche Bundesbank (2002), Kapitalgedeckte Altersvorsorge und Finanzmärkte, Monatsbericht, July: 25-39.

Ernst, K. and Fraktion DIE LINKE (2008), Leistungsniveau der Rente bei der gesetzlichen Rentenversicherung und der sogenannten Riesterrente, Bundestagsdrucksache I6/8312, 27 February.

Feldstein, M. (I997), The case for privatization, Foreign Affairs, 76, 4: 24-38. 
Glennester, H. and Evans, M. (I994), Beveridge and his assumptive worlds: the incompatibilities of a flawed design. In J. Hills and H. Glennester (eds), Beveridge and social security: an international perspective, Oxford: Oxford University Press, pp. 56-72.

Herden, I. (2006), Rente: Zwang zum privaten Glück, Capital (3I May).

Hills, J. (2008), Verbal evidence to Public Bills Committee on the Pensions Bill, fourth sitting, I7 January, http://www.publications.parliament.uk/pa/cm200708/ cmpublic/pensions/o8oir/pm/80ir7sor.htm (accessed 2i April 20II).

Hockerts, H. G. (1980), Sozialpolitische Entscheidungen in Nachkriegsdeutschland. Alliierte and deutsche Sozialversicherungspolitik: 1945-1957, Stuttgart: Klett-Cotta.

Indicators Sub-Group of the of the Social Protection Committee (ISG) (2009), Updates of Current and Prospective Theoretical Pension Replacement Rates, 2006-2046, Brussels: ISG, http://ec.europa.eu/social/main.jsp?catId=752\&langId=en (accessed 20 October 2009).

Kennedy, L. (2007), Germany's wise man of pensions, Investment Pensions Europe, 7 October.

Lau, M. (2008), Geißler fordert von Eliten mehr Geld, Die Welt, I5 April.

Marshall, T. H. (1975), Social Policy in the Twentieth Century, 4th edn, London: Hutchinson.

MDR (20II), Renten-Dialog: Von der Leyen präzisiert Plan für Zuschuss-Rente, http://www.mdr.de/nachrichten/renteri2.html (accessed 30 April 2012).

Meyer, D. and Meyer, J. (2006), Measuring Risk Aversion, Foundations and Trends in Microeconomics, 2, 2: 107-203.

Monitor (20I0), Bedrohliche Altersarmut: Riesterrente auf dem Prüfstein, 25 March, http://www.wdr.de/tv/monitor/sendungen/2010/0325/riester.php5 (accessed 2 I April 2011).

Munnell, A., Golub-Sass, A., Kopcke, R. and Webb, A. (2009), What does it cost to guarantee returns? Center for Retirement Research, Issue Brief 9-4, Boston, MA: Boston College.

National Association of Pension Funds (NAPF) (2005), Towards a Citizen's Pension: Final Report, London: NAPF.

National Employment Savings Trust (NEST) (201 I), Developing and delivering NEST's Investment Approach, London: NEST Corporation.

N24-EMNID (2008), Bundesbürger begrüßen Rüttgers Rentenvorschlag, http://www. presseportal.de/meldung/i I776I7/ (accessed 2i April 20II).

Oehler, A. with Kohlert, D. (2009), Alles Riester? Die Umsetzung der Förderidee in der Praxis, http://www.vzbv.de/mediapics/altersvorsorge_gutachen_oehler_I2_ 2009.pdf (accessed 2I April 20II).

Orzag, P. and Stiglitz, J. (200I), Rethinking pension reform: ten myths about social security systems. In R. Holzmann and J. Stiglitz (eds), New ideas about old-age security: Toward sustainable pension systems in the 2ist Century, Washington, DC: World Bank.

Pensions Commission (2004), Pensions - Challenges and Choices: The First Report of the Pensions Commission, London: The Stationery Office.

Pensions Commission (2005), A New Pension Settlement for the Twenty-First Century: The Second Report of the Pensions Commission, London: The Stationery Office.

Pensions Policy Institute (PPI) (2008), Incentives to save in a pension: a review of the PPI's research, Briefing Note Number 44, London: PPI.

Plusminus (2008), Riestern lohnt sich auf jeden Fall für den Staat, Interview mit Meinhard Miegel, http://www.daserste.de/plusminus/allround_dyn uid, f4ovcoqo33kgnwyu $\sim$ cm.asp (accessed 20 February 20I0).

Riester, W. (2008), Die Wirkungen der Rentenreform 200I im Vergleich zum Rentenrecht vor der Reform, http://www.walterriester.de/presse48.shtml (accessed 20 October 2009). 
Rohde, J. and Fraktion der FDP (2007), Altervorsorge für Geringverdiener attraktiv gestalten, Bundestagsdrucksache I6/7I77, I4 November.

Schmähl, W. (2007), Dismantling an earnings-related social pension scheme: Germany's new pension policy, Fournal of Social Policy, 36, 2: 319-40.

Schwenn, K. (2012), Reformpläne: Zuschussrente bis zu $85^{\circ}$ Euro für Geringverdiener, Frankfurter Allgemeine Zeitung, 8 March.

Scottish Widows (2008), The Scottish Widows UK Pensions Report, June, Edinburgh: Scottish Widows.

Select Committee (2003), The Future of UK Pensions, Third Report of the House of Commons Work and Pensions Select Committee, HC 92-I, Session 2002-2003, London: The Stationery Office.

Seeleib-Kaiser, M., Saunders, A. M. and Naczyk, M. (20I I), Social Protection Dualism, De-Industrialization and Cost Containment. In D. Brady (ed.), Comparing European Workers Part B: Policies and Institutions, Research in the Sociology of Work Vol. 22, Bingley: Emerald Group.

Social Protection Committee (SPC) (2008), Privately Managed Funded Pension Provision and Their Contribution to Adequate and Sustainable Pensions, Brussels: SPC, http://www. ec.europa.eu/employment_social/spsi/docs/social_protection_commitee/final_ 050608_en.pdf (accessed 20 February 20I0).

Sozialverband (2007), Sozialverband fordert Trennung der Riester-Rente von Grundsicherung, http://www.versicherungen-blog.net/2007/I2/or/sozialverbandfordert-trennung-der-riester-rente-von-grundsicherung/ (accessed io September 20II).

Spicker, P. (2011), How social security works: An introduction to benefits in Britain, Bristol: Policy Press.

Steffen, J. (2008), Grundsicherung im Alter und die 'Riester'-Rente, Bremen: Arbeitnehmerkammer Bremen.

SWR (2008), Streit um Riesterrente: Fast jeder soll riestern. Interview mit 'Finanztest' Chefredakteur Tenhagen, http://www.swr.de/ratgeber/geld/riesterinterview/-/ $\mathrm{id}={ }_{\mathrm{I}} 788 / \mathrm{nid}={ }_{\mathrm{I}} 788 / \mathrm{did}=3044948 / \mathrm{I} 652 \mathrm{eyg} /$ index.html (accessed 20 October 2009).

Taylor-Gooby, P. (2011), Does risk society erode welfare state solidarity? Policy \&尺 Politics, 39, 2: 147-6r.

Thomas, A., Jones, J., Davies, S. and Chilvers, D. (2009), Individuals' attitudes and behaviours around planning and saving for later life: Findings from qualitative and quantitative research, Working Paper No. 72, London: Department for Work and Pensions.

Timmins, N. and Barker, A. (2007), Conservative threat to pension consensus, Financial Times, 5 November.

Tomlinson, L. (20II), NAPF criticises NEST on means testing, Investment Pensions Europe, i6 February.

Turner, A. (2008), Verbal evidence to Public Bills Committee on the Pensions Bill, fourth sitting, I7 January, http://www.publications.parliament.uk/pa/cm200708/ cmpublic/pensions/o8ori7/pm/80ir7sor.htm (accessed 2i April 20ir).

Walker, R., Hardman, G. and Hutton, S. (I989), The occupational pension trap: towards a preliminary empirical specification, Fournal of Social Policy, I8, 4: 575-93.

WDR (2008), Monitor: Arm trotz Riester: Sparen fürs Sozialamt, Io January, http:// www.wdr.de/tv/monitor (accessed 2I April 2011).

Wehler, H.-U. (2008), Deutsche Gesellschaftsgeschichte. Band 5: Bundesrepublik und DDR I949-I990, Munich: C. H. Beck.

Which? (2007), Which? submits Pension White Paper response, press release, 26 March, http://www.which.co.uk/press/press_topics/campaign_news/personal_ finance/pension_white_paper_260307_57I_III352.jsp (accessed 20 October 2009). 